necessarily be the actual fundamental frequencies of $\mathrm{BaS}^{16} \mathrm{O}_{3}{ }^{18} \mathrm{O}$ but may be intermediate peaks between those of $\mathrm{BaS}^{16} \mathrm{O}_{3}{ }^{18} \mathrm{O}(87 \%)$ and the $\mathrm{BaS}^{18} \mathrm{O}_{4}(11.8 \%)$ present in the sample. This is more likely for the strongly absorbing broad $\nu_{3}$ peaks but, on the other hand, the $v_{1}$ peaks of $\mathrm{BaS}^{16} \mathrm{O}_{4}$ and $\mathrm{BaS}^{16} \mathrm{O}_{3}{ }^{18} \mathrm{O}$ are clearly resolved.

The infrared spectrophotometric method for the determination of $\mathrm{BaS}^{16} \mathrm{O}_{3}{ }^{18} \mathrm{O}$ is insensitive in comparison with the mass-spectrographic method (Hoerring, 1952; Spencer, 1958), which can readily distinguish differences of 0.01 atom $\%$ excess of ${ }^{18} \mathrm{O}$. Clearly, the infrared method can be of little use with samples containing low concentrations of ${ }^{18} \mathrm{O}$ or when small differences in isotope content between two samples are required to be measured, but for the study of the position of cleavage of sulphate esters by sulphatases, where an 'all or none' response can be expected, the method offers the advantages of speed and simplicity. For experiments of this type it is advisable to carry out the enzyme reactions in water containing at least 5 atoms \% excess of ${ }^{18} \mathrm{O}$, and the availability of such material constitutes the major limiting factor in the use of the method.

Application of the method to the study of the hydrolysis of $p$-nitrophenyl sulphate by the arylsulphatase of Aspergillus nidulans showed that the enzyme acts by cleaving the $\mathrm{O}-\mathrm{S}$ bond of the arylsulphate. On theoretical grounds (cf. Spencer, 1958) it may therefore be deduced that if the enzyme can act as a transferase it will transfer the sulphate rather than the phenol group. Inhibition studies indicate that the enzyme, which is similar to the arylsulphatase of Taka-diastase (Aspergillus oryzae), is a type I arylsulphatase and its method of action is also the same as other type I enzymes, namely rat-liver arylsulphatase $C$ and the arylsulphatase of Alcaligenes metalcaligenes, which are already known to split the $\mathrm{O}-\mathrm{S}$ bond. No actual transferring activity has yet been demonstrated for any type I arylsulphatase.

\section{SUMMARY}

1. The infrared-absorption spectra of normal barium sulphate and barium sulphate containing $87 \%$ of $\mathrm{BaS}^{16} \mathrm{O}_{3}{ }^{18} \mathrm{O}$ have been examined.

2. A method of estimating $\mathrm{BaS}^{16} \mathrm{O}_{3}{ }^{18} \mathrm{O}$ in barium sulphate has been developed, based on the measurement of relative extinctions at 981 and $961 \mathrm{~cm} .^{-1}$

3. The method has been used to analyse the barium sulphate prepared from the inorganic sulphate liberated by Aspergillus nidulans arylsulphatase acting on potassium $p$-nitrophenyl sulphate in the presence of water containing $8 \cdot 7$ atoms $\%$ excess of ${ }^{18} \mathrm{O}$. The $\mathrm{BaS}^{16} \mathrm{O}_{3}{ }^{18} \mathrm{O}$ content of the barium sulphate was found to be $7 \cdot 8 \%$, showing that the type I arylsulphatase of Aspergillus nidulans splits the O-S bond of arylsulphates.

I am most grateful to Dr E. Whittle and Mr C. G. Cannon for help with the infrared spectra. The investigation was supported in part by a Royal Society Grant and by a research grant (A-1982) from the U.S. Public Health Service.

\section{REFERENCES}

Bhagavantam, S. \& Venkatarayudu, T. (1951). Theory of Groups and Application to Physical Problems, 2nd ed. p. 127. Waltair, India : Andhra University.

Burkhardt, G. N. \& Lapworth, A. (1926). J.chem. Soc. p. 684. Dodgson, K. S. \& Spencer, B. (1957). In Methods of Biochemical Analysis. Ed. by Glick, D. New York: Interscience Publishers.

Duval, C. \& Lecomte, J. (1954). C.R. Acad. Sci., Paris, 239, 249.

Hass, M. \& Sutherland, G. B. B. M. (1956). Proc. Roy. Soc. A, 236, 427.

Herzberg, G. (1945). Molecular Spectra and Molecular Structure. New York: Van Nostrand Co.

Hoerring, T. (1952). Ph.D. Thesis: Washington University, U.S.A.

Kohlrausch, K. W. F. (1943). Ramanspektren. Hand-und Jahrbuch der chemischen Physik, vol. 9, pt. 6, p. 399. Leipzig: Akademische Verlagsgesellschaft.

Lloyd, A. G. (1959). Biochem. J. 72, 133.

Ramdas, A. K. (1954). Proc. Indian Acad. Sci. A, 39, 81. Spencer, B. (1958). Biochem. J. 69, 155.

\title{
The Acyl-Group Specificity of Choline Acetylase
}

\author{
BY J. F. BERRY* AND V. P. WHITTAKER \\ A.R.C. Institute of Animal Physiology, Babraham, Cambridge
}

(Received 13 March 1959)

Although much is known about the specificity of the cholinesterases, that of choline acetylase, the enzyme responsible for the synthesis of acetylcholine, has received relatively little attention. The

* Present address: Biochemistry Research Division, Department of Medicine, Sinai Hospital of Baltimore, Inc., Baltimore, Md., U.S.A. alkyl-group specificity of purified rat-brain choline acetylase has been investigated by Burgen, Burke \& Desbarats-Schonbaum (1956) with a number of choline analogues; limited studies of the acylgroup specificity of the enzyme in pigeon brain have been made by Gardiner \& Whittaker (1954) and Whittaker (1953) and in invertebrates by 
Nachmansohn \& co-workers (Korey, de Braganza \& Nachmansohn, 1951; Berman, Wilson \& Nachmansohn, 1953) and Frontali (1958).

It is now well established that the synthesis of acetylcholine from acetate and choline by nervous tissue in vitro occurs in two steps: first, the activation of acetate by acetic thiokinase in the presence of adenosine triphosphate and coenzyme $\mathbf{A}$ to form acetyl coenzyme $A$; secondly, the transfer of the acetyl group from coenzyme A to choline by choline acetylase. [The nomenclature recommended in Biochem. $J$. (1956) 64, 782, is used here.] In the present investigation, the acyl-group specificity of sheep-, pigeon- and rat-brain choline acetylase preparations was studied by coupling the enzyme to a crude acyl thiokinase preparation from pigeon liver, capable of activating all the fatty acids investigated. This necessitated preliminary experiments designed to establish the activation spectrum of the liver preparation and the concentration of adenosine triphosphate, coenzyme $\mathbf{A}$, inorganic ions and acyl thiokinase needed to ensure that formation of acyl-coenzyme A was not rate-limiting. The acyl thiokinase activity of the crude brain preparations was also studied; the rate of activation of fatty acids was found, with some species variation, to decrease markedly with increasing chain length, thus emphasizing the need for supplementation with the liver thiokinase.

The use of an acyl-coenzyme A donor system was preferred to the use of stoicheiometric amounts of synthetic acyl-coenzyme A derivatives because there is good evidence that the latter do not give, even in purified systems, as high a rate of acylcholine synthesis as is obtainable with the donor system. Thus Whittaker (1953) found that the rate of acetylcholine synthesis from acetyl-coenzyme $A$ by crude pigeon-brain preparations was less than $10 \%$ of that obtained in the presence of pigeonbrain acetic thiokinase, and Berman et al. (1953) reported that purified squid-ganglion choline acetylase synthesized acetylcholine from acetylcoenzyme $A$ at only $30 \%$ of the rate obtained with a donor system consisting of acetylphosphate, coenzyme $\mathbf{A}$ and bacterial phosphotransacetylase. Similar observations have been made by Smallman (1958) on rabbit brain. The reason for this effect is not fully understood, but may be related to the presence of acetate acceptors other than choline.

The results presented here show that crude brain preparations were able to synthesize all the $n$-acylcholines up to $C_{6}$ (the highest tested) and also palmitoylcholine. The products of the reaction were identified chromatographically. Liver preparations alone were unable to synthesize the lower choline esters, but could form palmitoylcholine at a higher rate than brain. Pigeon brain was selected for detailed study because of its high activity, and fractionation by the procedure of Kumagai \& Ebashi (1954) revealed the presence of three enzymes. One, for which the term 'choline acetylase' is reserved, catalysed the formation of acetyl- and propionyl-choline only, the latter at about $30 \%$ of the acetylcholine rate, and corresponded to the enzyme in guinea-pig brain purified by Kumagai \& Ebashi. The enzyme responsible for the synthesis of the intermediate homologues (up to $\mathrm{C}_{6}$ ) was inactivated by the purification procedure, and its acyl-group optimum was not determined. It is proposed that this enzyme be provisionally termed 'choline acylase II'. The third enzyme, recovered in a discarded fraction from the Kumagai \& Ebashi purification, was responsible for the synthesis of palmitoylcholine. Its acyl-group optimum was not determined and the provisional designation 'choline acylase III' is proposed. Since choline acetylase and choline acylase II are analogous to acetocholinesterase and pseudocholinesterase respectively, it was of interest to see whether a palmitoylcholinesterase analogous to choline acylase III could be identified in tissues. This proved to be so, and the distribution of the enzyme in different tissues was studied.

Of interest in view of the frequent use of cysteine as a component of the reaction mixture in choline acetylase determinations was the finding that $N S$. diacetylcysteine was formed from acetyl-coenzyme $A$ and cysteine in the presence of liver extracts. The formation of this compound may give rise to discrepancies between the ferric hydroxamate (Hestrin 1949) and bioassay methods of measuring cholineester formation. Competition between cysteine and choline for acyl-coenzyme $A$ derivatives was avoided by replacing cysteine by borohydride.

\section{METHODS}

\section{Preparation of acetone-dried powders}

Acetone-dried powders of pigeon and sheep livers (intended primarily for activation studies) were prepared essentially as described by Kaplan \& Lipmann (1948). Acetone-dried powders of pigeon and sheep brain, sheep caudate nucleus and rat tissues were prepared by pounding the tissue in a cold mortar with $10 \mathrm{vol}$. of acetone at $-8^{\circ}$ to $-15^{\circ}$ followed by homogenization in a high-speed blendor for 2-5 min. (cf. Hebb, 1955).

\section{Activation studies}

For activation studies, acetone-dried powders were extracted with $0.02 \mathrm{M}-\mathrm{KHCO}_{3}(20-100 \mathrm{mg} . / \mathrm{ml}$.), and the supernatant fluid, separated by centrifuging at $1200 \mathrm{~g}$ for 3-5 min. at $0^{\circ}$, was used as the source of enzyme. The rate of activation was measured with hydroxylamine as a trapping agent for activated acyl groups or spectrophotometrically as described below. The reaction mixture (I) contained in $2.0 \mathrm{ml}$, unless otherwise stated, $\mathbf{M g C l}_{\mathbf{2}}$ (20 $\mu$ moles), $\mathrm{KCl}(100 \mu$ moles), coenzyme A (CoA) (Pabst, 
70\% pure) $(0 \cdot 1 \mu \mathrm{mole})$, adenosine triphosphate (ATP) (Pabst, dipotassium salt, free of non-adenine nucleotides) (10 $\mu$ moles), $\mathrm{KBH}_{4}(1 \mu$ mole $)$, fatty acid $(20 \mu$ moles $)$ as ammonium (palmitate) or sodium salt (other acids), hydroxylamine hydrochloride $(500 \mu$ moles $)$. The reagents were adjusted to $\mathrm{pH} 7 \cdot 0$ with $2 \mathrm{~N}-\mathrm{NaOH}$ before adding enzyme. The pH was selected with subsequent cholineacetylase experiments in view. The mixture was incubated for $1 \mathrm{hr}$. at $37^{\circ}$. The acylhydroxamic acid formed was estimated by the procedure of Beinert et al. (1953). The reaction mixture was cooled to $0^{\circ}, 1 \mathrm{ml}$. of $3 \mathrm{~N}-\mathrm{HCl}$ and $1 \mathrm{ml}$. of $\mathrm{FeCl}_{3}\left[5 \%(\mathrm{w} / \mathrm{v}) \mathrm{FeCl}_{3}, 6 \mathrm{H}_{2} \mathrm{O}\right.$ in $\left.0 \cdot 1 \mathrm{~N}-\mathrm{HCl}\right]$ were added, the suspension was centrifuged and the extinction at $540 \mathrm{~m} \mu$ compared with those of zero-time samples and tubes from which ATP and CoA had been omitted. Activation of palmitate was measured by the method of Lipmann \& Tuttle (1950) or in some experiments by that of Lipmann \& Tuttle $(1945 a)$ by using larger quantities of $\mathrm{CoA}$ and adding hydroxylamine at the end of the incubation. The amount of activation occurring was measured by the increase in acylhydroxamate concentration during the incubation, resulting from the presence of CoA and ATP (corrected for acylhydroxamate formation from endogenous fatty acid).

\section{Choline-acylase studies}

Extraction and incubation. The extraction of the enzyme from brain acetone-dried powders and the composition of the incubation mixture were as described for acyl thiokinase, with the following modifications. The extraction medium was usually $0.155 \mathrm{M}-\mathrm{NaCl}$, but in a few preliminary experiments $0.025 \mathrm{M}$-cysteine hydrochloride neutralized with $\mathrm{NaOH}$ in $0.19 \mathrm{M}-\mathrm{NaCl}$ or, neutralized with $\mathrm{KOH}$, in $0.19 \mathrm{M}-\mathrm{KCl}$, or $0.0028 \mathrm{M}-\mathrm{KH}_{2} \mathrm{PO}_{4}-0.0042 \mathrm{M}-\mathrm{K}_{2} \mathrm{HPO}_{4}$ buffer (pH 7.0) in $0.05 \mathrm{M}-\mathrm{KCl}$ (Nachmansohn \& John, 1945) was used as indicated. The reaction mixture (II) contained, in addition to $\mathrm{MgCl}_{2}, \mathrm{KCl}, \mathrm{CoA}, \mathrm{ATP}, \mathrm{KBH}_{4}$ and fatty acid in the same concentrations as in (I), eserine sulphate $(0 \cdot 1 \mu$ mole), $\mathrm{KHCO}_{3}$ extract from $20 \mathrm{mg}$. of acetone-dried pigeon liver $(0.2 \mathrm{ml}$.) and extract of acetone-dried brain. Choline chloride $(20 \mu$ moles $)$ replaced hydroxylamine as acyl-group acceptor. Controls containing no brain extract showed that pigeon liver alone was unable to acylate choline except in the presence of palmitate.

Assay. The ester formed during the incubation was estimated in $1 \mathrm{ml}$. samples of the reaction mixture by the method of Hestrin (1949) (short-chain esters) or Lipmann \& Tuttle (1950) (palmitate). Short-chain esters were also estimated after deproteinization by bioassay with the rectus abdominis muscle of the frog. Samples were chilled, brought to $\mathrm{pH} \mathrm{4-4.5}$, heated at $100^{\circ}$ for $10 \mathrm{~min}$., cooled and centrifuged and the supernatant fluid was assayed by the method of Chang \& Gaddum (1933) as modified by Feldberg \& Hebb (1947), with acetylcholine as standard. The activity divided by the ester content of a sample (in molar units) gave the relative molar potency of the ester which could be compared with that of an authentic sample of the expected ester, synthesized as described by Keyl, Michaelson \& Whittaker (1957), as a means of identifying the product of the enzyme reaction. Choline (free and esterified) was estimated by treating deproteinized samples with an equal volume of saturated aqueous ammonium reineckate at $0^{\circ}$, collecting the precipitate by centrifuging, dissolving it in $2 \mathrm{ml}$. of acetone and measuring $E_{540 \mathrm{~m} \mu}$.
Chromatographic identification of choline esters. This was carried out by the methods of Gardiner \& Whittaker (1954) and Whittaker \& Wijesundera (1952). For column chromatography, a deproteinized sample of the reaction mixture was placed on a column of Amberlite XE-97 buffered to $\mathrm{pH} 4 \cdot 3,0.6 \mathrm{~cm}$. in diameter and $10-12 \mathrm{~cm}$. in height, and eluted with $0 \cdot 1 \mathrm{M}-\mathrm{NaH}_{2} \mathrm{PO}_{4}$. Esters were located in successive fractions of the eluate by bioassay. Portions of eluted material were freeze-dried and extracted three times with $3 \mathrm{ml}$. of cold ethanol, the extracts evaporated and taken up in the least volume of mM-acetate buffer, pH 4.5. The solution was passed through De-Acidite FF (The Permutit Co. Ltd., London, $-16+50$ mesh) in the chloride form to replace other anions by chloride, applied to Whatman no. 1 filter paper and chromatographed in butanol saturated with water by the ascending method. Palmitoylcholine and palmitic acid were applied in ethanol and run similarly. Compounds were located by exposure to iodine vapour, by spraying with hydroxylamine and $\mathrm{FeCl}_{3}$ (Whittaker \& Wijesundera, 1952), or bromocresol purple (Reid \& Lederer, 1951), or by elution of successive areas and assay on the frog rectus.

\section{Purification of choline acylases}

Pigeon-brain choline acetylase. This was purified as described by Kumagai \& Ebashi (1954).

Pigeon-liver choline acylase III. This was purified from $\mathrm{KHCO}_{3}$ extracts of liver acetone powders by $\left(\mathrm{NH}_{4}\right)_{2} \mathrm{SO}_{4}$ fractionation. Precipitates were dissolved in the minimum volume of $0.02 \mathrm{M}-\mathrm{KHCO}_{3}$ and dialysed against $0.02 \mathrm{M}$ $\mathrm{KHCO}_{3}$. All operations were carried out at $0^{\circ}$.

Protein. This was estimated by the method of Kalckar (1947) or by a micro-Kjeldahl procedure.

\section{Spectrophotometric studies}

Fatty acid activation and acylation of choline were followed spectrophotometrically by measuring the change in $E_{230 \mathrm{~m} \mu}$ due to the formation and disappearance of the thio ester group of acyl-CoA. Measurements were made in the Hilger Uvispek spectrophotometer; the reaction was followed discontinuously, as described by Mahler, Wakil \& Bock (1953) and Hele (1954), or continuously, as described by Stadtman (1953), and satisfied the conditions regarding the final thiol-thio ester ratio discussed by Kielley, Stadtman \& Bradley (1954). When followed discontinuously, the reaction mixture was as already described for choline acetylase (mix ture II) except that the initial volume was $3.0 \mathrm{ml}$., $\mathrm{KCl}$ was omitted, $0.9 \mu$ mole of $\mathrm{CoA}$ was used, the concentration of pigeon-liver thiokinase was adjusted to give approximately equal rates of activation with different substrates, lower $\left(\mathrm{C}_{2}-\mathrm{C}_{6}\right)$ fatty acids were added as their potassium salts and choline and eserine were added after a steady-state concentration of acyl-CoA had been attained. Samples $(0.2 \mathrm{ml}$.) were withdrawn at zero time and successive $5 \mathrm{~min}$. periods thereafter, added to $0.8 \mathrm{ml}$. of $0.1 \mathrm{M}$ -

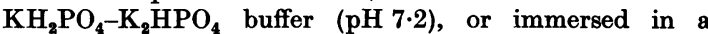
boiling-water bath for a few minutes, diluted with $3.0 \mathrm{ml}$. of water and filtered. When followed continuously, the reaction mixture consisted of $\mathrm{MgCl}_{2}(3 \mu \mathrm{moles})$, CoA (0.1 $\mu$ mole), ATP (3 $\mu$ moles), $\mathrm{KBH}_{4}$ (1 $\mu$ mole), ammonium salt of the fatty acid $(6 \mu$ moles $)$ and enzyme in a total volume of $3.0 \mathrm{ml}$. When the activation reaction was complete, choline chloride $(2 \mu$ moles $)$ and eserine sulphate 
$(0.1 \mu \mathrm{mole})$ were added and the decline in extinction accompanying the transfer of the acyl group from acylCoA to choline was observed.

\section{Esterase studies}

Esterase measurements were carried out at $37^{\circ}$, in $0.023 \mathrm{M}-\mathrm{NaHCO}_{3}$ buffered to $\mathrm{pH} 7.4$ with $\mathrm{CO}_{2}$, by the Warburg manometric technique as modified by Ammon (1933). Gum acacia $(0.2 \%)$ was added as stabilizer in experiments with purified enzymes. Activity was expressed in $Q$ units (i.e. $\mu$ l. of acid produced $/ \mathrm{mg}$. dry wt. of enzyme/hr.) or as $\mu \mathrm{l} . / 100 \mathrm{mg}$. wet wt. of tissue/hr. Harvard plasma fraction IV-6 $\left(Q_{\text {Acetylcholine }} 690\right)$, kindly supplied by Dr D. M. Surgenor, or Cholase brand purified human-plasma cholinesterase (Cutter Laboratories) $\left(Q_{\text {Acetylcholine }} 3300\right)$ and purified bovine-red-cell cholinesterase (Winthrop Stearns Inc.) $\left(Q_{\text {Acetylcholine }} 97000\right)$ served as sources of purified butyro- and aceto-cholinesterase respectively. For tissue distribution studies, $10 \%(w / v)$ homogenates of pigeon and rat tissues were prepared in $0.023 \mathrm{M}-\mathrm{NaHCO}_{3}$ and preserved at $0^{\circ}$ in the presence of a few drops of chloroform until required. With palmitoylcholine as substrate activity declined rapidly after $10 \mathrm{~min}$. even in the presence of gum acacia. Accordingly, activity measurements were made only during the initial $10 \mathrm{~min}$. period with this substrate.

\section{RESULTS}

\section{Activation studies}

Effect of sodium ions on activation. Sodium ions (Korff, 1953) have been stated to be inhibitory to acetic thiokinase; yet $\mathrm{NaCl}$ has been used by previous workers to extract choline acetylase from brain tissue. Accordingly, the effect of this ion on acetate activation by pigeon liver was studied. Table 1 shows that $\mathrm{NaCl}$ had no inhibitory action on acetate activation and it was therefore thought legitimate to use $\mathrm{NaCl}$ for extracting choline acetylase. In experiments with brain, no difference was found in the rate of activation or choline ester synthesis whichever of the extractants mentioned in the Methods section was used. Brain and liver acetic thiokinase activities were additive.

Activation of various fatty acids by liver and brain. Table 2 shows the relative abilities of extracts of acetone-dried powders of pigeon and sheep liver and brain and rat liver to activate a series of fatty acids. The results show that in acetone-dried powders of brain from both pigeon and sheep activation declines rapidly with increasing chain length, though sheep brain appears to be more active on the longer-chain fatty acids than is pigeon brain. On the other hand, in acetone-dried powders of liver of all three species, activation tends to increase with increasing chain length. In the light of recent studies by Vignais, Gallagher \& Zabin (1958), acetone-dried powders may not represent the best preparation for studying fatty acid activation by brain for all substrates. The main purpose of these experiments was to find out what contribution, if any, to the total activating potential

\section{Table 1. Effect of sodium and potassium ions on acetate activation by extracts of pigeon-liver acetone-dried powder}

Reaction mixture I as described in the text was used with the following modifications: sodium acetate was replaced by the potassium salt; hydroxylamine hydrochloride was neutralized with $\mathrm{KOH}$; volume of extract $0.2 \mathrm{ml}$., equivalent to $20 \mathrm{mg}$. of powder and containing $2.0 \mathrm{mg}$. of $\mathrm{N}$; $\mathrm{NaCl}(200 \mu$ moles $)$ was added and $\mathrm{KCl}$ omitted as indicated. Acetate activation was measured by hydroxamate formation.

Rate of acetate activation ( $\mu$ moles/g. of powder/hr.)

Complete system without additions

$\mathrm{NaCl}$ added

$42 \cdot 5$

$\mathrm{NaCl}$ added, no $\mathrm{KCl}$
$43 \cdot 0$

$45 \cdot 0$

\section{Table 2. Activation of various fatty acids by extracts from acetone-dried powders of pigeon} and sheep liver and brain and rat liver

Reaction mixture I as described in text was used. Volumes of extracts: pigeon liver, $0 \cdot 2 \mathrm{ml}$., equivalent to $20 \mathrm{mg}$. of powder, containing $2.0 \mathrm{mg}$. of $\mathrm{N}$; pigeon brain, $1.0 \mathrm{ml}$., equivalent to $20 \mathrm{mg}$. of powder, $1.9 \mathrm{mg}$. of $\mathrm{N}$; sheep liver, $0.5 \mathrm{ml}$., equivalent to $20 \mathrm{mg}$. of powder, $0.69 \mathrm{mg}$. of $\mathrm{N}$; sheep brain, $0.5 \mathrm{ml}$, equivalent to $10 \mathrm{mg}$. of powder, $1.77 \mathrm{mg}$. of $\mathrm{N}$; rat liver, $0.5 \mathrm{ml}$., equivalent to $10 \mathrm{mg}$. of powder.

Rate of acylhydroxamate formation ( $\mu$ moles/g. of powder/hr.)

\begin{tabular}{|c|c|c|c|c|c|}
\hline & \multicolumn{5}{|c|}{ tencos } \\
\hline & \multicolumn{2}{|c|}{ Pigeon } & \multicolumn{2}{|c|}{ Sheep } & \multirow{2}{*}{$\begin{array}{c}\text { Rat } \\
\text { Liver }\end{array}$} \\
\hline & Liver & Brain & Liver & Brain* & \\
\hline Acetate & $51 \cdot 0$ & $16 \cdot 5$ & $28 \cdot 0$ & $18 \cdot 1$ & $25 \cdot 0$ \\
\hline Propionate & $37 \cdot 5$ & $7 \cdot 0$ & $34 \cdot 5$ & $9 \cdot 4$ & $23 \cdot 0$ \\
\hline$n$-Butyrate & $40 \cdot 5$ & $2 \cdot 5$ & $36 \cdot 0$ & $9 \cdot 4$ & $26 \cdot 0$ \\
\hline$n$-Valerate & $54 \cdot 0$ & $2 \cdot 0$ & $82 \cdot 0$ & $5 \cdot 4$ & $38 \cdot 0$ \\
\hline Hexanoate & $69 \cdot 0$ & 0.5 & $125 \cdot 0$ & $5 \cdot 4$ & $47 \cdot 0$ \\
\hline Palmitate & $80 \cdot 0$ & 0 & $62 \cdot 0$ & $5 \cdot 4$ & $69 \cdot 0$ \\
\hline
\end{tabular}

* Similar values were obtained with sheep caudate nucleus. 
Table 3. Properties of reaction product, compared with NS-diacetylcysteine

Observations: +, positive; -, negative; a, not investigated.

$R_{F}$ in butanol saturated with water Fe-hydroxamate reaction in alkaline solution

Ninhydrin reaction

Nitroprusside reaction

Frog-rectus assay

Solubility

Absorption maximum $(\mathrm{m} \mu)$

$10^{-3} \epsilon_{231 \mathrm{~m} \mu}$
* Noda et al. (1953).

\begin{tabular}{|c|c|c|c|c|}
\hline $\begin{array}{c}\text { Reaction } \\
\text { product }\end{array}$ & $\begin{array}{c}\text { Same after } \\
\text { alkaline } \\
\text { hydrolysis }\end{array}$ & $\begin{array}{c}\text { Synthetic } \\
N S \text {-diacetyl- } \\
\text { cysteine }\end{array}$ & $\begin{array}{c}\text { Same after } \\
\text { alkaline } \\
\text { hydrolysis }\end{array}$ & Cysteine \\
\hline $0 \cdot 11$ & 0 & $0 \cdot 12$ & 0 & 0 \\
\hline+ & - & + & - & - \\
\hline - & + & - & + & + \\
\hline - & + & - & + & + \\
\hline - & - & - & - & - \\
\hline Ether + & a & Ether + & $\mathbf{a}$ & $\mathbf{a}$ \\
\hline 231 & a & 231 & a & $\mathbf{a}$ \\
\hline $4 \cdot 06$ & $\mathbf{a}$ & $4 \cdot 10$ & $\mathbf{a}$ & a \\
\hline$*$ & tal. (1953) & $3 \cdot 90^{*}$ & & \\
\hline
\end{tabular}

Same after
alkaline hydrolysis

Cysteine

0

0

$-$

$+$

$+$

$+$

a

a

a

\begin{tabular}{|c|c|c|c|c|}
\hline $\begin{array}{c}\text { Reaction } \\
\text { product }\end{array}$ & $\begin{array}{c}\text { Same after } \\
\text { alkaline } \\
\text { hydrolysis }\end{array}$ & $\begin{array}{c}\text { Synthetic } \\
N S \text {-diacetyl- } \\
\text { cysteine }\end{array}$ & $\begin{array}{l}\text { Same after } \\
\text { alkaline } \\
\text { hydrolysis }\end{array}$ & Cysteine \\
\hline $0 \cdot 11$ & o & $0 \cdot 12$ & 0 & 0 \\
\hline+ & - & + & - & - \\
\hline - & + & - & + & + \\
\hline- & + & - & + & + \\
\hline- & - & - & - & - \\
\hline Ether + & a & Ether + & $\mathbf{a}$ & $\mathbf{a}$ \\
\hline 231 & a & 231 & a & $\mathbf{a}$ \\
\hline $4 \cdot 06$ & $a$ & $4 \cdot 10$ & a & $a$ \\
\hline$* N$ & tal. (1953). & $3 \cdot 90^{*}$ & & \\
\hline
\end{tabular}

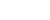

(n)

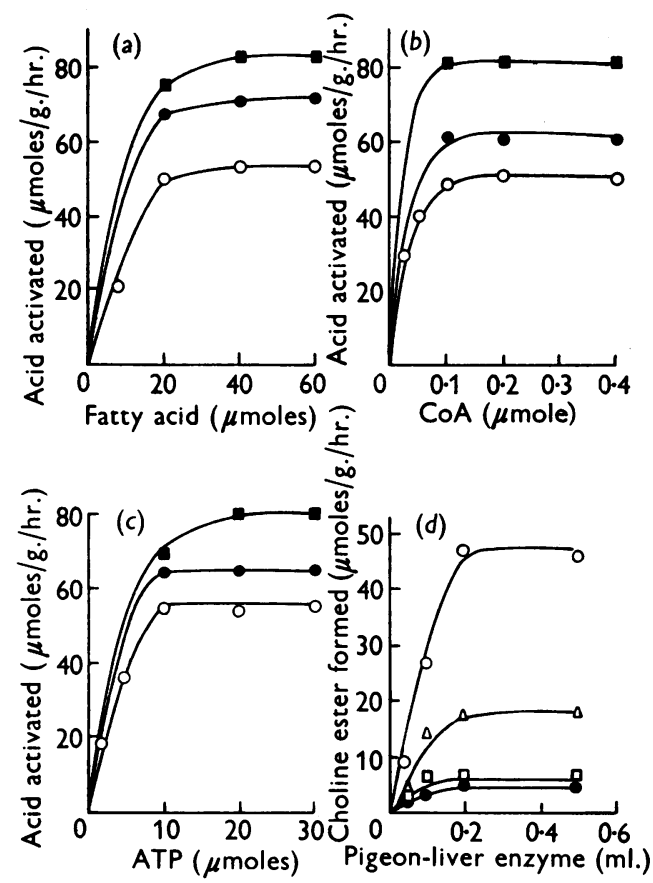

Fig. 1. Dependence of activating enzyme of pigeon liver on (a) substrate, (b) CoA and (c) ATP, and of crude pigeonbrain choline-acetylase preparation on $(d)$ pigeon-liver activating enzyme. $O$, Acetate; $\triangle$, n-butyrate; $\square$, $n$-valerate; $\bigcirc$, hexanoate; $\square$, palmitate. Reaction mixtures: $(a, b, c)$ as in Table 2 , except that concentrations of fatty acid, CoA and ATP were varied as indicated; $(d)$ reaction mixture II, using $1.0 \mathrm{ml}$. of extract of pigeon brain (equivalent to $20 \mathrm{mg}$. of acetone-dried powder) except that the volume of pigeon-liver extract was varied as indicated.

of the coupled system the brain extracts would make. They emphasize the desirability of coupling a liver-activating system with brain for the study of the acyl specificity of the brain choline acylase.
Since the pigeon-liver preparation was the most active per mg. of acetone-dried powder, it was used as the source of activating enzyme, and the optimum conditions for its use for acylcholine synthesis were studied as described in the next section.

Investigation of optimum conditions for synthesis of acylcholine. In order to obtain conditions in which the activation reaction was not rate-limiting in choline-ester synthesis, the dependence of the activation reaction on concentrations of fatty acid, CoA and ATP was determined. The results are shown in Fig. 1a-c. The rate of activation by the pigeon-liver system was not much changed after the amounts of CoA exceeded $0 \cdot 1 \mu \mathrm{mole}$, ATP, $10 \mu$ moles and fatty acid, $20 \mu$ moles. These amounts were therefore used. Also (Fig. 1d) choline-ester formation was not increased with these concentrations of substrate and cofactors by raising the volume of pigeon-liver preparation above $0.2 \mathrm{ml}$., equivalent to $20 \mathrm{mg}$. acetone-dried powder. Choline-ester formation was also unchanged by increases in CoA, ATP and fatty acid concentrations above those required for optimum activation.

Formation of NS-diacetylcysteine. In initial experiments when $20 \mu$ moles of neutralized cysteine hydrochloride were used in each tube in place of borohydride as a sulphydryl-group reductant, there was a discrepancy between the acetylcholine assays by the frog rectus and the Hestrin (1949) methods. In the absence of either choline or an extract of brain acetone-dried powder, no acetylcholine was formed as measured by the bioassay procedure, yet the Hestrin (1949) procedure showed the formation of $20 \mu \mathrm{moles}$ of ester $/ \mathrm{g}$. of powder/hr. The formation of the compound was CoA- and ATP-dependent and ceased if cysteine was replaced by potassium borohydride. The properties of the compound are summarized in Table 3. 
The $R_{r}$ in butanol saturated with water was close to that of acetylcholine. The alkaline hydrolysis product was identified as cysteine. Accordingly, $N S$-diacetylcysteine was prepared by the method of Neuberger (1938). Both the reaction product and the synthetic compound had the absorption maximum at $231 \mathrm{~m} \mu$ characteristic of these esters and the molar extinction coefficients of both specimens were close to that reported by Noda, Kuby \& Lardy (1953) for NS-diacetylcysteine. The mechanism of formation of the compound was assumed to be as follows: acetyl-CoA reacts with cysteine either non-enzymically (Stadtman, 1952 ; Stadtman \& White, 1953) or via pigeonliver thioltransacetylase (Brady \& Stadtman, 1954) to form $S$-acetylcysteine. This compound is unstable and becomes rearranged to $N$-acetylcysteine, which could then offer the sulphydryl group once more as an acetyl-group acceptor to form the stable $N S$-diacetylcysteine. Since its formation is CoAdependent, it is unlikely that thiolesterase (Strecker, Mela \& Waelsch, 1955) is involved.

\section{Acyl-group specificity of crude and purified brain-choline-acetylase preparations}

Specificity of crude brain preparations. Table 4 (columns 2, 4, 5 and 6) shows the ability of crude brain-choline-acetylase preparations from pigeon, sheep and rat to synthesize choline esters from a series of fatty acids in the presence of pigeon-liver acyl thiokinase and optimum concentrations of the components of the activating system. It will be seen that all these preparations are able to synthesize all the choline esters up to $n$-valerylcholine though at decreasing rates relative to acetylcholine. Pigeon and sheep brain could also synthesize hexanoylcholine. Pigeon and rat brain were also able to synthesize palmitoylcholine. The rates for acetylcholine synthesis are within the ranges reported by Hebb (1957). Unlike the other esters palmitoylcholine was also synthesized by the liver preparation alone; in Table 4 the contribution of the liver enzyme has been subtracted from the total palmitoylcholine synthesis.

\section{Table 4. Specificity of crude and purified brain-choline-acetylase preparations}

Reaction mixture II as described in the text was used. Vol. of brain extracts: unpurified extract from whole pigeon brain, $1.0 \mathrm{ml}$., equivalent to $20 \mathrm{mg}$. of powder, containing $1.9 \mathrm{mg}$. of $\mathrm{N}$; 22-fold purified pigeon-brain choline acetylase, $0.1 \mathrm{ml}$., equivalent to $26 \mathrm{mg}$. of powder, containing $0.06 \mathrm{mg}$. of $\mathrm{N}$ and $0.22 \mathrm{mg}$. of protein; extract of sheep brain, $0.5 \mathrm{ml}$., equivalent to $10 \mathrm{mg}$. of powder, $0.88 \mathrm{mg}$. of $\mathrm{N}$; sheep caudate nucleus, $0.3 \mathrm{ml}$., equivalent to $5.5 \mathrm{mg}$. of powder, $0.10 \mathrm{mg}$. of $\mathrm{N}$; rat brain, $0.5 \mathrm{ml}$., equivalent to $50 \mathrm{mg}$. of powder.

Choline-acylase activity ( $\mu$ moles/g. of powder/hr.)

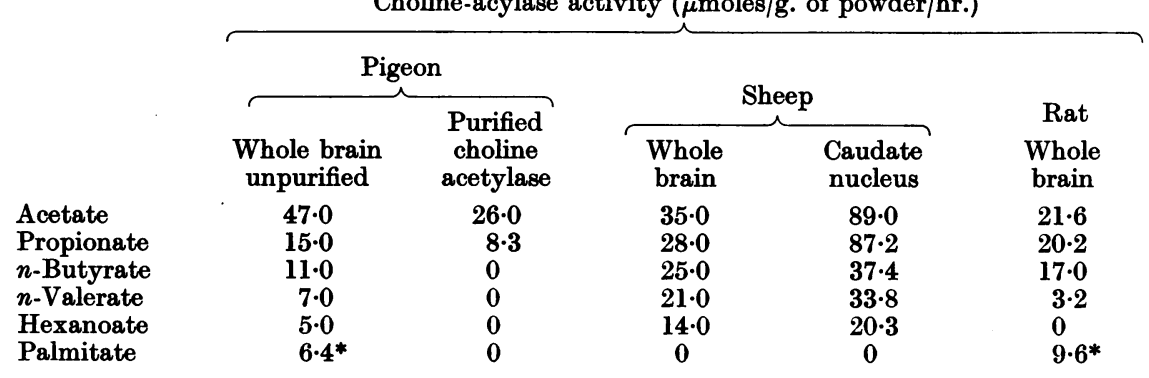

* Corrected for contribution to total palmitoylcholine synthesis by pigeon-liver extract.

Table 5. Comparison of properties of choline esters synthesized by pigeon-brain extract with those of synthetic esters

\begin{tabular}{|c|c|c|c|c|c|c|c|c|c|}
\hline \multirow[b]{3}{*}{ Compound } & \multicolumn{4}{|c|}{ Synthetic choline ester } & & \multicolumn{4}{|c|}{ Isolated choline ester } \\
\hline & \multirow[b]{2}{*}{$R_{F}$} & \multicolumn{2}{|c|}{ Retention vol. (ml.) } & \multirow[b]{2}{*}{$\begin{array}{l}\text { Relative } \\
\text { molar } \\
\text { potency }\end{array}$} & \multirow[b]{2}{*}{$\begin{array}{l}\text { Fatty acid } \\
\text { added }\end{array}$} & \multirow[b]{2}{*}{$\boldsymbol{R}_{\boldsymbol{F}}$} & \multicolumn{2}{|c|}{ Retention vol. (ml.) } & \multirow[b]{2}{*}{$\begin{array}{c}\text { Relative } \\
\text { molar } \\
\text { potency }\end{array}$} \\
\hline & & $\begin{array}{c}\text { Elution } \\
\text { peak }\end{array}$ & $\begin{array}{c}\text { Displace- } \\
\text { ment peak }\end{array}$ & & & & $\begin{array}{l}\text { Elution } \\
\text { peak }\end{array}$ & $\begin{array}{l}\text { Displace- } \\
\text { ment peak }\end{array}$ & \\
\hline Choline & 0.08 & 25 & - & - & None & 0.08 & 20 & - & - \\
\hline Acetylcholine & $0 \cdot 10$ & 40 & - & 100 & Acetate & $0 \cdot 12$ & 36 & - & 100 \\
\hline Propionylcholine & 0.22 & 55 & - & 154 & Propionate & $0 \cdot 25$ & 55 & - & 150 \\
\hline$n$-Butyrylcholine & $0 \cdot 28$ & 60 & - & 125 & $n$-Butyrate & 0.29 & 60 & - & 123 \\
\hline$n$-Valerylcholine & $0 \cdot 31$ & 140 & - & 40 & $n$-Valerate & 0.30 & 130 & - & 33 \\
\hline Hexanoylcholine & $0 \cdot 36$ & $>160$ & 2 & 20 & $n$-Hexanoate & 0.34 & - & 7 & 15 \\
\hline
\end{tabular}




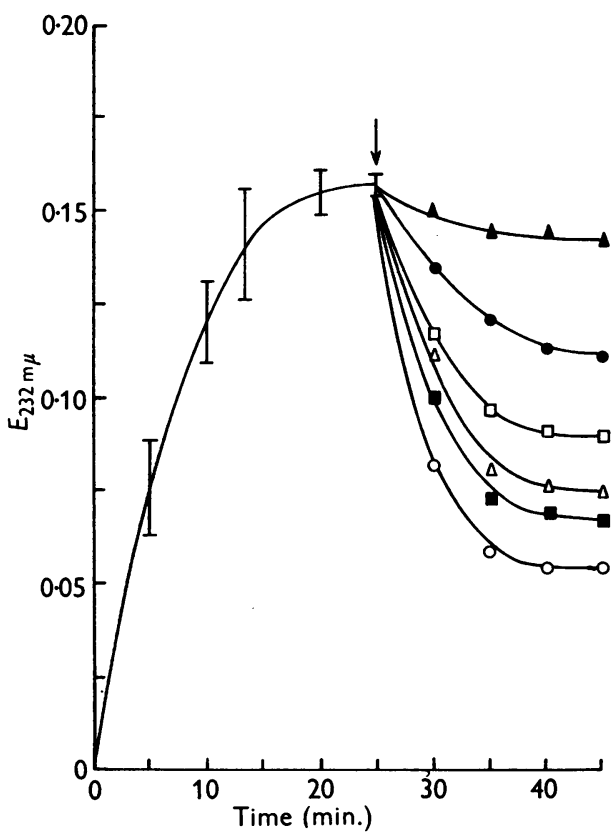

Fig. 2. Spectrophotometric determination of fatty acid activation by pigeon-liver and -brain extracts and deacylation in the presence of choline. The reaction medium was as described in the text for discontinuous spectrophotometry and contained $0 \cdot 2-0 \cdot 6 \mathrm{ml}$. of extract of pigeon-liver acetone-dried powder, equivalent to 20 $60 \mathrm{mg}$. of powder and containing $2 \cdot 0-6 \cdot 0 \mathrm{mg}$. of $\mathrm{N}$, and $1.0 \mathrm{ml}$. of extract of pigeon brain, equivalent to $20 \mathrm{mg}$. of powder, $1.9 \mathrm{mg}$. of $\mathrm{N}$. Choline and eserine were added at $\downarrow$. $\bigcirc$, Acetate; $\triangle$, propionate; $\square, n$-butyrate; $O$, $n$-valerate; $\Delta$, hexanoate; $\boldsymbol{D}$, palmitate. The concentration of liver extract was adjusted to give approximately equal rates of activation; the points on this part of the curve are averages irrespective of substrate, and the bars through the points represent the range of values averaged.
Characterization of products. Since fatty acids can in certain circumstances be oxidized to acetylCoA, it was important to identify the products of the reaction, although it was observed that no reduction of di- or tri-phosphopyridine nucleotide occurred in the presence of fatty acids with any of the preparations studied. Accordingly, these were characterized by chromatographic and, where possible, biological tests. Some results are shown in Table 5. The $R_{p}$ values, retention volumes and relative molar potencies of the esters synthesized by the pigeon-brain preparation are all in good agreement with those of the corresponding synthetic esters, which in turn are close to the values obtained by Keyl et al. (1957). Palmitoylcholine, not included in Table 5, proved to be difficult to identify chromatographically owing to its ability to form stable complexes with palmitic acid. Its identification is discussed in a section below describing its synthesis by liver preparations.

Spectrophotometric studies. The activation and acylation reactions were further studied in a stepwise manner as shown in Fig. 2, which shows the increase in $E_{232 \mathrm{~m} \mu}$ due to the formation of acyl-CoA and the subsequent decrease in extinction due to the disappearance of acyl-CoA as the acyl group is transferred to choline. For all fatty acids, a steadystate concentration of acyl-CoA appears to be attained by $20 \mathrm{~min}$. Presumably the steady-state concentration of acyl-CoA represents a balance between continued synthesis and destruction by deacylases and other enzymes present in the preparation. On adding choline, the steady-state concentration is rapidly lowered to a new level, and the difference in the two steady-state concentrations may be taken as the amount of choline ester synthesized. That this is correct is shown by Table 6, which shows good agreement between the spectrophotometric results and the amount of ester

Table 6. Comparison of spectrophotometric, bioassay and chemical methods of determining choline-acylase activity

Experimental conditions were as in Fig. 2.

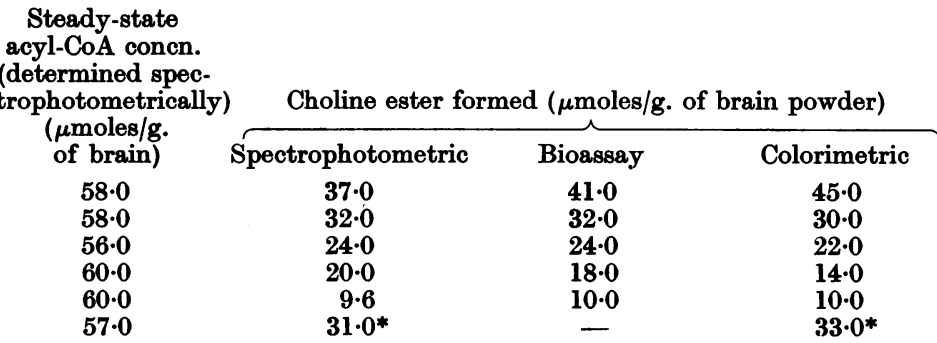

Fatty acid
Acetate
Propionate
$n$-Butyrate
$n$-Valerate
Hexanoate
Palmitate

* $\mu$ moles/g. of brain + liver powders. 
synthesized in the same samples as determined by the bioassay and colorimetric procedures, with the appropriate synthetic esters as standards. The results for palmitate here represent the combined effect of brain and liver.

Specificity of purified preparations. In order to investigate whether the spectrum of activity in Table 4 was due to a single enzyme or a mixture of enzymes, acetone-dried powder extracts of brain were purified by the method of Kumagai \& Ebashi (1954). Pigeon brain was selected for this study because of its high activity/mg. of acetone-dried powder. The purified enzyme (column 3) proved to be able to synthesize only acetyl- and propionylcholine. The rate of synthesis of acetylcholine by the purified preparation $(0.57 \mathrm{mg}$. of acetylcholine chloride/mg. of protein $/ \mathrm{hr}$.) is comparable with that reported by Kumagai \& Ebashi. The discarded fractions were therefore examined for choline-acylase activity. None of the fractions showed activity when coupled with a pigeon-liver system containing butyrate, valerate or hexanoate. However, palmitoylcholine synthesis was obtained with the precipitate from the first acetic acid precipitation. These results demonstrate that the specificity pattern shown by the crude pigeon-brain extract is a composite due to at least three separate choline acylases. The first acylase synthesizes acetyl- and to a lesser extent propionyl-choline. It would be appropriate to reserve the term choline acetylase for this enzyme. The second enzyme (choline acylase II) synthesizes butyryl-, valeryland hexanoyl-choline. It probably contributes little to the synthesis of propionylcholine, since the ratio of the rates of synthesis of propionyl- to acetyl-choline hardly changed as a result of purification. Whether it makes a contribution to acetylcholine synthesis cannot be determined as yet. This enzyme was either destroyed during the purification or was rendered inactive in some other way, e.g. by removal of an unsuspected cofactor. Palmitoylcholine synthesis seems to be brought about by yet another enzyme (choline acylase III). This enzyme does not catalyse the synthesis of any of the lower acylcholines either in brain or liver, since liver preparations alone, although much more active in synthesizing palmitoylcholine than brain, were unable to synthesize any of the lower acylcholines.

In view of the higher choline acylase III activity of liver, the enzyme was further studied in this tissue.

\section{Pigeon-liver choline acylase III}

Cofactor requirements. Table 7 shows the results of attempts to demonstrate the cofactor requirements of choline acylase III. The system requires CoA, ATP and palmitate (columns 4 and 5, rows 2-4). A requirement for choline could not be demonstrated in the crude liver preparation,

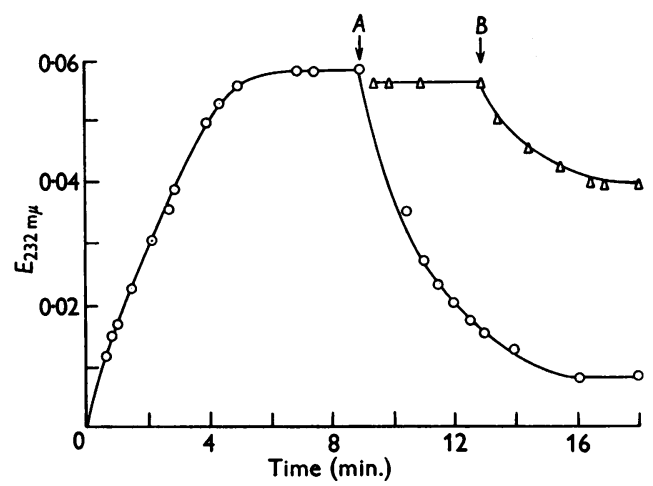

Fig. 3. Palmitoyl-group activation and transfer by a purified pigeon-liver preparation. The reaction mixture was as described in the text for continuous spectrophotometry, and contained $0.5 \mathrm{ml}$. of purified liver enzyme equivalent to $32.5 \mathrm{mg}$. of original acetone-dried powder and containing $0.11 \mathrm{mg}$. of $\mathrm{N}$ and $1.13 \mathrm{mg}$. of protein. At $A$, choline chloride and eserine were added to a portion of the intact system $(O)$ and to a portion boiled at that time $(\triangle)$. Fresh enzyme was added to the boiled system at $B$.

\section{Table 7. Cofactor requirements for palmitate esterification by crude and purified pigeon-liver preparations}

The complete system was reaction mixture II as described in the text but containing no brain extract, and either $0.2 \mathrm{ml}$. of extract of pigeon-liver acetone-dried powder (equivalent to $20 \mathrm{mg}$. of powder) (crude system) or $0.2 \mathrm{ml}$. of fourfoldpurified fraction (equivalent to $20 \mathrm{mg}$. of original powder and containing $3.16 \mathrm{mg}$. of protein and $0.39 \mathrm{mg}$. of $\mathrm{N}$ ) (purified system).

Conditions

Complete system

Complete system less palmitate

Complete system less CoA

Complete system less ATP

Complete system less choline

Complete system less enzyme
Choline

Choline added ( $\mu$ moles)

20

20

20

20

0

20 $23 \cdot 4$ $25 \cdot 4$ $4 \cdot 3$ $14 \cdot 0$
Ester formed recovered from crude system ( $\mu$ moles)

$\overbrace{\begin{array}{c}\text { Crude } \\ \text { system }\end{array}}^{(\mu \text { moles/g. of powder) }}$

$30 \cdot 1$

0

0

40.0

0
$23 \cdot 0$

0

0

0

0 
apparently owing to the presence of sufficient quantities of choline in the tissue extract. Column 3 gives the amount of choline recovered as the reineckate from the reaction mixture: $3 \cdot 4-5 \cdot 4$ (average, 4.4) $\mu$ moles of choline were recovered in excess of any which could be accounted for by added choline. This corresponds to $30 \mathrm{mg}$. of choline chloride/g. of liver powder. The total amount present is probably more, since only $\mathbf{7 0} \%$ of added choline was recovered from the reaction mixture in the absence of enzyme.

An attempt was made to remove choline and to separate the activating enzyme from the choline acylase by fractionating the liver extract with ammonium sulphate. Acylase activity was found in the fractions precipitated when the concentration of ammonium sulphate was raised from 30 to $50 \mathrm{~g} . / 100 \mathrm{ml}$. of extract, but these fractions also contained the thiokinase activity. Refractionation increased the specific activity without separating the enzymes. However, the choline dependence of the reaction could now be demonstrated, as shown in Table 7, column 5, row 5, and Fig. 3. In the latter, the activation reaction may be seen as the increase in $E_{232 \mathrm{~m} \mu}$ and the synthesis of palmitoylcholine as the decrease in extinction on addition of choline chloride and eserine. If the preparation is boiled after a steady-state concentration of acyl-CoA is reached, addition of choline chloride does not cause a fall in extinction until fresh enzyme is added. These results indicate the enzymic and stepwise nature of the reaction.

Chromatographic identification of enzymically synthesized palmitoylcholine. Experiments with mixtures of synthetic palmitoylcholine and palmitic acid showed that these compounds had a strong tendency to form a stable complex. Methods which appeared promising when evaluated with the two compounds separately (e.g. reversed-phase column chromatography, paper electrophoresis) failed to separate mixtures, especially those in which the acid component was in excess, as in the enzyme studies. Thus, although the two compounds had different $R_{F}$ values in butanol and water (palmitoylcholine $0 \cdot 70$, palmitic acid 1.0), when chromatographed together they tended to travel as a single spot of intermediate $R_{F}$. Palmitic acid was tenaciously retained by columns of the strongly basic resin De-Acidite FF (as the chloride form in ethanol), whereas palmitoylcholine passed through. However, only $70 \%$ of palmitic acid was retained when palmitoylcholine was also present.

However, in two experiments, enzymically synthesized palmitoylcholine was successfully identified after chromatography as a spot of $R_{F} \mathbf{0 . 7 2}$ which gave a brown colour with iodine vapour, formed a hydroxamate under alkaline conditions and gave an alkaline reaction with bromocresol purple, reactions given by synthetic palmitoylcholine but not by palmitic acid. The spot was negative to ninhydrin and showed no phosphorus by the method of Hanes \& Isherwood (1949); therefore it could not have contained a phospholipid.

The material was isolated from the protein-free supernatant, after incubation, by precipitation with an equal volume of ice-cold saturated aqueous ammonium reineckate. The washed precipitate was taken up in $50 \%(\mathrm{v} / \mathrm{v})$ aqueous acetone and passed through a column of De-Acidite FF in the chloride form to remove reineckate ion and unesterified palmitate. The effluent material was evaporated to dryness in vacuo and taken up in ethanol. Palmitoylcholine was tenaciously retained by Amberlite XE-97 and was extensively hydrolysed on alumina, so that chromatography on these materials was impracticable.

\section{Palmitoylcholine esterase}

The existence in brain and liver of a distinct choline acylase concerned with the synthesis of palmitoylcholine raised the question whether this compound was hydrolysed by tissues, and if so, by known cholinesterases or a separate enzyme.

Effect of butyro- and aceto-cholinesterases. Palmitoylcholine was not significantly hydrolysed ( $<0.2 \%$ of the acetylcholine rate) by either of the preparations of purified human-plasma butyrocholinesterase. The ester was tested at 2 and $10 \mathrm{~mm}$ concentrations by using concentrations of enzyme up to 100 times that required to give a rapid carbon dioxide evolution with $30 \mathrm{~mm}$-acetylcholine. The purified bovine-red-cell acetocholinesterase failed to hydrolyse $10 \mathrm{~mm}$-palmitoylcholine detectably at a concentration 10 times that giving a rapid hydrolysis of $10 \mathrm{~mm}$-acetylcholine (74 $\mu \mathrm{l} . / 10 \mathrm{~min}$.).

Owing to the surface-active nature of palmitoylcholine, it was thought possible that its failure to be hydrolysed might be due to a non-specific inactivation of the enzyme by the substrate, analogous to that observed by Mounter (1952) with cobra-venom cholinesterase and water-immiscible substrates, even though $0.2 \%$ of gum acacia had been added as a stabilizing agent. $2 \mathrm{mM}$-Palmitoylcholine inhibited acetylcholine hydrolysis by cholase by $100 \%$; under similar conditions $30 \mathrm{~mm}$ gave $20 \%$ inhibition. However, this inhibition was $83 \%$ reversible by 1: 100 dilution and $67 \%$ reversible by dialysis for 15-20 hr.; the smaller inhibition by $30 \mathrm{~mm}$-choline was $100 \%$ reversible in parallel experiments. Thus the inhibition of butyrocholinesterase by palmitoylcholine is mainly reversible and the failure of the enzyme to hydrolyse this substrate cannot be ascribed either to enzyme inactivation or to a failure of the enzyme and ester to interact. 
Hydrolysis by pigeon and rat tissues. Hydrolysis of palmitoylcholine could be demonstrated manometrically in pigeon and rat tissues with $10 \%(\mathrm{w} / \mathrm{v})$ homogenates in aq. $0.2 \%(w / v)$ sodium bicarbonate, as shown in Table 8. The general trend of activity is the same in both species, liver being the most active tissue of those examined, followed by spleen, intestine, kidney and pancreas. Brain, heart, lung and skeletal muscle showed low or negligible activity. There was no correlation between the palmitoylcholinesterase activity of the various tissues and their cholinesterase contents as measured by three different standard substrates. As pigeon liver was the most active source of the enzyme, some additional studies were made with this tissue. The system obeyed the simple MichaelisMenten kinetics, $10 \mathrm{~mm}$-palmitoylcholine giving a nearly maximum initial velocity. The Michaelis constant was estimated to be $4.0 \mathrm{mM}$. The enzyme was not inhibited by $10^{-4} \mathrm{M}$-eserine or $10^{-5} \mathrm{M}$ diisopropyl phosphofluoridate. The insensitivity of the enzyme to these high concentrations of anticholinesterases, its different distribution in the tissues from known cholinesterases and the inability of purified aceto- and butyro-cholinesterases to hydrolyse palmitoylcholine is conclusive evidence that the palmitoylcholine-hydrolysing esterase is distinct from other cholinesterases, but its relation to tissue lipases and aliesterases has not been established.

The low level of the enzyme in pigeon brain is contrary to the findings of Gomori (1948). The low level of activity might be due to absence of activating ions such as $\mathrm{Ca}^{2+}, \mathrm{Mg}^{2+}$ and $\mathrm{Co}^{2+}$, or to destruction of enzyme due to the detergent quality of the substrate or competitive inhibition by excess of substrate, but these explanations were made unlikely by the following observations. Addition of $\mathrm{Ca}^{2+}, \mathrm{Mg}^{2+}$ and $\mathrm{Co}^{2+}$ up to $30 \mathrm{~mm}$ failed to increase the esterase activity; no increase of activity occurred even with a substrate concentration as low as $0.5 \mathrm{~mm}$, and ammonium palmitate, also surface-active, produced only $27 \%$ inhibition of pigeon-brain acetocholinesterase at $10 \mathrm{~mm}$.

\section{DISCUSSION}

Our results confirm and extend those of Gardiner \& Whittaker (1954) and Whittaker (1953) in showing that crude vertebrate-brain choline-acetylase preparations can synthesize a series of homologous choline esters. Unlike the earlier workers, instead of relying on the endogenous acyl thiokinase of brain preparations, we used a fortified system in which acyl-CoA derivatives were supplied at a nonlimiting rate by a pigeon-liver acyl thiokinase preparation. In these circumstances, the relative rates of choline-ester synthesis may be taken to provide a true picture of the acyl-group specificity of the enzymes concerned. The work with purified extracts shows that pigeon-brain choline acetylase has a high degree of specificity, being able to synthesize only acetyl- and propionyl-choline, and suggests that the synthesis of the short-chain homologues of these esters is catalysed by a second choline acylase with an apparent acyl-group optimum near butyrate. If choline acetylase be regarded as the counterpart of acetocholinesterase, this enzyme may be that of brain pseudocholinesterase, though it is not known how specific it is for the acyl-group acceptor. The eserine insensitivity and CoA- and ATP-dependence of the reaction would seem to exclude the possibility that this enzyme is pseudocholinesterase acting in reverse (Hestrin, 1950), but its identity with a nonspecific thiolesterase which can utilize choline in place of water as an acyl-group acceptor is not excluded. A comparison of the work of Korey et al. (1951) with unpurified and those of Berman et al. (1953) with purified squid-ganglion preparations suggests that this tissue also contains choline acylase II, though the pharmacologically active material synthesized by the crude ganglion preparation in the presence of butyrate was not

Table 8. Palmitoylcholine esterase activity of pigeon and rat tissue

Activities are expressed as $\mu \mathrm{l} . / 100 \mathrm{mg}$. wet wt. of tissue/hr.

\begin{tabular}{|c|c|c|c|c|c|c|}
\hline & & & & & & \\
\hline & $\begin{array}{l}10 \text { mM- } \\
\text { Palmitoyl- } \\
\text { choline }\end{array}$ & $\begin{array}{l}30 \text { mm- } \\
\text { Butyryl- } \\
\text { choline }\end{array}$ & $\begin{array}{l}30 \text { mM- } \\
\text { Benzoyl- } \\
\text { choline }\end{array}$ & $\begin{array}{c}30 \mathrm{~mm}- \\
\text { Acetyl- } \beta \text { - } \\
\text { methylcholine }\end{array}$ & $\begin{array}{l}10 \text { mM- } \\
\text { Palmitoyl- } \\
\text { choline }\end{array}$ & $\begin{array}{c}30 \text { mM- } \\
\text { Butyryl- } \\
\text { choline }\end{array}$ \\
\hline Liver & 204 & 670 & 36 & 56 & 164 & 200 \\
\hline Spleen & - & - & - & - & 38 & 216 \\
\hline Intestine & 108 & 340 & 200 & 34 & 12 & 1800 \\
\hline Kidney & 108 & 234 & 0 & 52 & 16 & 162 \\
\hline Pancreas & 32 & 240 & 76 & 26 & - & - \\
\hline Brain & 6 & 52 & 12 & 2000 & 4 & 162 \\
\hline Heart & 0 & 280 & 0 & 96 & 12 & 840 \\
\hline Lung & 0 & 0 & 24 & 8 & 6 & 124 \\
\hline Muscle & 0 & 30 & 0 & 0 & 0 & 6 \\
\hline
\end{tabular}


positively identified by Korey et al. as butyrylcholine. The same omission renders dubious the significance of the observation of Torda \& Wolff (1945) that a homologous series of fatty acids increased acetylcholine synthesis by minced frog brain. On the other hand, fly brain does not appear to contain the second enzyme (Frontali, 1958).

The physiological significance of the synthesis of pharmacologically active homologues of acetylcholine by brain tissue is not at present clear. Although the results presented here were obtained with fortified systems, there is little doubt that the acyl thiokinase activity of the brain itself is adequate for synthesis of these esters. However, although propionylcholine has been found in ox spleen (Banister, Whittaker \& Wijesundera, 1953; Gardiner \& Whittaker, 1954; Augustinsson, 1955; Henschler, 1957), it is doubtful whether homologues of acetylcholine occur in brain tissue. Holtz \& Schümann (1954) have reported the presence of butyrylcholine in ox brain, but Henschler (1956) has stated that this compound appears only in autolysing brain. M. J. Keyl \& V. P. Whittaker (unpublished work) were unable to identify any active acetylcholine homologues in ox, sheep, goat or rabbit brain. Thus if these homologues are capable of being synthesized in brain tissue in vivo, there must be an effective mechanism for preventing their accumulating even in small amounts.

The finding of palmitoylcholine-synthesizing and -hydrolysing enzymes distinct from those involved in the metabolism of the lower esters is interesting in relation to Kennedy's (1956) isolation from tissues of an alkali-labile lipid-like compound containing no phosphorus with properties similar to those of palmitoylcholine. According to Kennedy, incorporation of labelled choline into this compound also required ATP and CoA. As with the short-chain homologues of acetylcholine, the significance of palmitoylcholine in brain metabolism is difficult to evaluate. Although the rate of palmitate activation by pigeon brain (the species in which palmitoylcholine synthesis was mainly studied) was too low to be measured, there seems little doubt that brain tissue can activate the longer-chain fatty acids, and optimum conditions may not have prevailed in these experiments. For example, hydroxylamine is known to be inhibitory to activating and other enzymes in certain circumstances (Mahler et al. 1953; Hele, 1954; Lipmann \& Tuttle, 1945b; Raw, 1953). The recent work of Vignais et al. (1958) provides additional evidence for palmitate activation in brain.

\section{SUMMARY}

1. The acyl-group specificity of crude and purified brain-choline-acetylase preparations from pigeon, sheep and rat has been studied. The preparations were coupled to a pigeon-liver activating system as a source of acyl-coenzyme $\mathbf{A}$ derivatives.

2. In preliminary experiments, the activation spectrum of extracts of liver and brain and the optimum conditions for activation were studied in order to ensure that the formation of acyl-coenzyme A derivatives was not a rate-limiting step. The rate of activation by liver extracts increased with increasing chain length, but the reverse was true of brain.

3. Cysteine, used by previous workers as a component of the choline-acetylase system, was found to act as an acyl-group acceptor and was replaced by borohydride.

4. Crude brain preparations were able to synthesize all the choline esters from acetate to hexanoate and also palmitoylcholine. Purification studies showed that three enzymes were involved.

5. Palmitoylcholine synthesis was studied in brain and in liver. It required coenzyme $A$ and adenosine triphosphate as well as palmitate and choline, and the two-stage nature of the synthesis was demonstrated.

6. Palmitoylcholine hydrolysis was catalysed by an enzyme in tissues which was distinct from known cholinesterases.

This work was carried out in 1956-57 during the tenure at Babraham of a National Multiple Sclerosis Society Fellowship by J.F.B., who wishes to express his gratitude to Sir Rudolph Peters, F.R.S., for generously extending the facilities of the Department of Biochemistry to him. The authors' thanks are also due to Miss J. Gilson for skilled technical assistance.

\section{REFERENCES}

Ammon, R. (1933). Pflüg. Arch. ges. Physiol. 233, 486. Augustinsson, K.-B. (1955). Acta chem. scand. 9, 793.

Banister, J., Whittaker, V. P. \& Wijesundera, S. (1953). J. Physiol. 121, 55.

Beinert, J., Green, D. E., Hele, P., Hift, H., Korff, R. W. von \& Ramakrishnan, C. V. (1953). J. biol. Chem. 203, 35.

Berman, R., Wilson, I. B. \& Nachmansohn, D. (1953). Biochim. biophys. Acta, 12, 315.

Brady, R. O. \& Stadtman, E. R. (1954). J. biol. Chem. 211, 621.

Burgen, A. S. V., Burke, G. \& Desbarats-Schonbaum, M. (1956). Brit. J. Pharmacol. 11, 308.

Chang, C. H. \& Gaddum, J. H. (1933). J. Physiol. 79, 255.

Feldberg, W. \& Hebb, C. O. (1947). J. Physiol. 106, 8.

Frontali, N. (1958). J. insect Physiol. 1, 319.

Gardiner, J. E. \& Whittaker, V. P. (1954). Biochem. J. 58, 24.

Gomori, G. (1948). Proc. Soc. exp. Biol., N.Y., 68, 354.

Hanes, C. S. \& Isherwood, F. A. (1949). Nature, Lond., 164, 1107.

Hebb, C. O. (1955). Quart. J. exp. Physiol. 40, 176.

Hebb, C. O. (1957). Physiol. Rev. 37, 196.

Hele, P. (1954). J. biol. Chem. 206, 671. 
Henschler, D. (1956). Hoppe-Seyl. Z. 305, 97.

Henschler, D. (1957). Hoppe-Seyl. Z. 309, 276.

Hestrin, S. (1949). J. biol. Chem. 180, 249.

Hestrin, S. (1950). Biochim. biophys. Acta, 4, 310.

Holtz, P. \& Schümann, H. G. (1954). Naturwissenschaften, 41, 306.

Kalckar, H. M. (1947). J. biol. Chem. 167, 461.

Kaplan, N. O. \& Lipmann, F. (1948). J. biol. Chem. 174, 37.

Kennedy, E. P. (1956). Canad. J. Biochem. Physiol. 34, 334.

Keyl, M. J., Michaelson, I. A. \& Whittaker, V. P. (1957). J. Physiol. 139, 434.

Kielley, W. W., Stadtman, E. R. \& Bradley, L. B. (1954). In Glutathione: $A$ Symposium, p. 57. Ed. by Colowick, S. P. et al. New York: Academic Press Inc.

Korey, S. R., de Braganza, B. \& Nachmansohn, D. (1951). J. biol. Chem. 189, 705.

Korff, R. W. von (1953). J. biol. Chem. 203, 265.

Kumagai, H. \& Ebashi, S. (1954). Nature, Lond., 173, 871. Lipmann, F. \& Tuttle, L. C. (1945a). J. biol. Chem. 159, 21.

Lipmann, F. \& Tuttle, L. C. (1945b). J. biol. Chem. 161, 415.

Lipmann, F. \& Tuttle, L. C. (1950). Biochim. biophys. Acta, 4, 301.

Mahler, H. R., Wakil, S. J. \& Bock, R. M. (1953). J. biol. Chem. 204, 453.
Melchior, N. C. \& Melchior, J. B. (1956). Science, 124, 402.

Mounter, L. A. (1952). Biochem. J. 50, 122.

Nachmansohn, D. \& John, H. M. (1945). J. biol. Chem. 158, 157.

Neuberger, A. (1938). Biochem. J. 32, 1452.

Noda, L. H., Kuby, S. A. \& Lardy, H. A. (1953). J. Amer. chem. Soc. 75, 913.

Raw, I. (1953). Science, 118, 159.

Reid, R. L. \& Lederer, M. (1951). Biochem. J. 50, 60.

Smallman, B. N. (1958). J. Neurochem. 2, 119.

Stadtman, E. R. (1952). J. biol. Chem. 196, 535.

Stadtman, E. R. (1953). J. cell. comp. Physiol. 41, Suppl. 1, 89.

Stadtman, E. R. \& White, F. H. (1953). J. Amer. chem. Soc. 75, 2022.

Strecker, H. J., Mela, P. \& Waelsch, H. (1955). J. biol. Chem. 212, 223.

Torda, C. \& Wolff, H. G. (1945). Proc. Soc. exp. Biol., N.Y., 59, 246.

Vignais, P. M., Gallagher, C. H. \& Zabin, I. (1958). J. Neurochem. 2, 283.

Whittaker, V. P. (1953). Unpublished results quoted in Lectures on the Scientific Basis of Medicine, vol. 6, p. 198. Ed. by Fraser, F. R. London: Athlone Press.

Whittaker, V. P. \& Wijesundera, S. (1952). Biochem. J.51, 348.

\title{
Gontrolled Biosynthesis of Actinomycin with Sarcosine
}

\author{
By E. KATZ AND W. A. GOSS \\ Institute of Microbiology, Rutgers, The State University, New Brunswick, New Jersey, U.S.A.
}

\section{(Received 3 April 1959)}

The actinomycins represent a family of chromopeptide antibiotics which differ solely in the nature of the amino acids present in the peptides of the molecule (Fig. 1). It has been established that an actinomycin-producing organism generally synthesizes a mixture of these substances. For example, Streptomyces antibioticus forms a mixture consisting of actinomycins I-V; occasionally trace amounts of a sixth component are produced (Katz \& Goss, 1958). Streptomyces chrysomallus produces actinomycins IV, VI and VII (SchmidtKastner, 1956b).

The quantitative and qualitative nature of the actinomycin mixture synthesized can be modified to a considerable extent; in particular, the nitrogen source supplied has been shown to have a profound influence on its composition. Actinomycin IV increased from 10 to $83 \%$ of the mixture produced by $S$. chrysomallus when DL-valine was added to the medium (Schmidt-Kastner, 1956b); hydroxy-Lproline brought about an increase in synthesis of actinomycin I from 6-7 to $31 \%$ of the actinomycins produced by $S$. antibioticus (Katz \& Goss, 1958).
New actinomycins were formed by S. chrysomallus when DL-isoleucine or sarcosine was added to the medium (Schmidt-Kastner, 1956a). In our Laboratory it has been determined that $S$. antiobiticus forms at least one new actinomycin with sarcosine and several new compounds when DL-pipecolic acid is used.

During an investigation of the role of amino acids on actinomycin synthesis by $S$. antibioticus, it was observed that sarcosine selectively stimulated the production of actinomycins II and III (Fig. 2). These components, normally synthesized in trace amounts, represented approximately $60 \%$ of the actinomycin mixture formed under the nutritional conditions employed. By paper-chromatography techniques, it was established that actinomycin II contains threonine, valine, sarcosine, and $N$ methylvaline, whereas actinomycin III possesses, in addition, one-half the amount of proline found in actinomycin IV (Katz, Goss \& Pugh, 1958). Recently Johnson \& Mauger (1959) obtained quantitative data showing that 4 moles of sarcosine and no proline are present in actinomycin II, and 